\title{
HISTOLOGICAL RESEARCH OF DRONES' SPERM MIGRATION IN THE REPRODUCTIVE TRACTS OF QUEEN BEES
}

\author{
V. D. BROVARSKYI, Doctor of Agricultural Sciences, Professor, \\ department of Horse-Breeding and Beekeeping \\ https://orcid.org/0000-0002-7228-4730 \\ National University of Life and Environmental Sciences of Ukraine \\ E-mail: vbrovarskiy@ukr.net
}

\begin{abstract}
The research studies sperm migration of drones labeled with fluorescent membrane probes in the reproductive system of bee uterus under various variants of its artificial introduction. It is established that individual doses of sperm of different drones when introduced into the fallopian tubes of the uterus, migrating into the spermateca are placed in layers without significant mixing. It has been found that in odd and even oviducts, sperm lose mobility. On the contrary, with the introduction of sperm into the area of the vaginal opening of the bee uterus, the sperm continue to actively move. It has been proven that during the physiological function of sperm leakage, spermateca from the various portions in the area adjacent to the family line are blotted for egg contamination. The introduction of semen into the area of the vaginal opening with a single portion of several drones helps to mix it in the process of migration in the fallopian tubes and sperm. On the contrary, with the unique introduction of fluorescent membrane probes labeled with doses of sperm of drones at certain intervals, it is possible to direct the reproductive activity of the uterus to obtain predominantly homogenous offspring of parental origin. In this case, the introduction of the sperm of different drones are placed in the spermateca of the uterus in layers, without significant mixing.
\end{abstract}

Keywords: drones' sperm, migration, queen bees

\section{Introduction.}

Drones' sperm, after natural breeding or artificial deposition, migrates in reproductive tracts of the queen bee, then it gets into spermatheca to be stored for a long time and is used for fertilization of eggs. The question of further individuality of its portions under the single live covering, physiology of viability of spermatozoids and ef- ficiency of fertilizing process by them during the whole period of egg deposition, is still considered to be just about the most important one in the biology of reproduction of individuals of species Apis mellifera L. (Ruttner, 1976; Ruttner, 1984; Ruttner, 1989; Schley, 1988; Scrive, 1989; Winston, 1991, Woyke, Lasinski, 1992).

Our histological research of the reproductive system of queen bees, which 
got the marked sperm from different drones into the unpaired oviduct, established definite common factors of spreading of reproductive production of drones in the spermatheca. However, the results received are not sufficient enough for precise analysis of sperm's migration processes in the reproductive organs of the queen bee. In natural conditions, a queen bee can fly out for breeding several times and pair with a different number of drones. In the process of pairing, sperm can initially get into the zone of the opening of the vagina and later migrates to the oviducts. Besides, each drone produces a different amount of sperm. So, as a rule, portions of sperm different in size and volume penetrate the reproductive tract of the queen bee. Migrating from the oviducts unequal number of spermatozoids of different drones will also penetrate spermatheca. That is why there is a necessity of further research migration of drones' sperm in reproductive tracts of queen bees.

The purpose of the research is to study the peculiarities of migration of drones' sperm in the reproductive tracts of queen bees under conditions of unnatural injection of reproductive stuff in the opening zone of the vagina.

\section{Research methods.}

To carry out these experiments, we used our unique methods (Brovarskiy, 1987; Brovarskiy, 2000). Unmated queen bees, coming into the breeding period, $(n=5)$ were divided into three groups. The queen bees in the $1^{\text {st }}$ group got drones' sperm labeled with fluorescent membrane probes only once and those of the $2^{\text {nd }}$ and $3 \mathrm{~d}$ groups -3 times in the zone of vagina's opening, using an artificial mating sign (Browar- skij, 2004). Each queen bee of groups $1 \& 2$ got $9 \mathrm{mcl}$ of sperm marked with (the amount of each marked portion was $3 \mathrm{mcl}$ ). For the queen bees of the $3 \mathrm{~d}$ groups other amounts of sperm were used, which were injected (correlation: 2 $\mathrm{mcl}$ with probe $\mathrm{A}, 5 \mathrm{mcl}$-probe $\mathrm{B}$, and 2 $\mathrm{mcl}$ with probe $\mathrm{C}$ ). Once the queen bees started laying eggs, they were removed from the brood nests, fixed, embedded in the thickening material and their reproductive system undergone histological research (Brovarskyi, 1999). Received histological slices were examined under a microscope MBI-15 (magnifying power appr.8x 10), described and then photographed.

\section{The results of the research.}

Based on the conducted research, there were received histological slices of the reproductive organs of the queen bees, some of them are shown in pictures 1-11.

In the first experimental group, where the queen bees were fixed $5 \mathrm{~min}$ utes after a single injection of the labeled fluorescent membrane probes $\mathrm{A}$, $\mathrm{B}$, and $\mathrm{C}$ sperm portions, the distribution of the reproductive function of different drones on histological slices was following (pic. 1). It was defined that after an unnatural injection, sperm marked by the probe A, filled empty spaces of the low part of a sting chamber around the artificial mating sign. It is explained by the fact that it was injected into the sting chamber the last and it pushed back the previous portions to the walls of the sting chamber.

Next portion of sperm, labeled with probe $\mathrm{B}$, was partly mixed with the other marked portions and was placed closer to the sidewalls of the sting chamber. A small part of this sperm was found in the vagina over the valve. The lower 


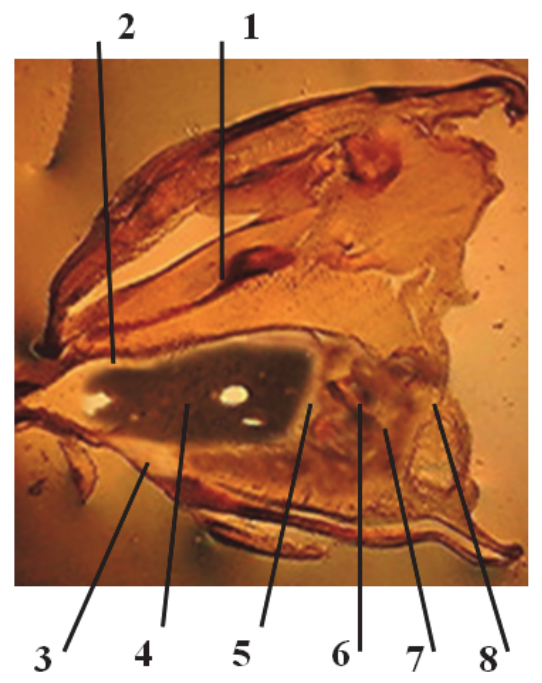

Pic. 1 Sagittal section of the reproductive system of the queen bee, undergone a single injection of sperm into the unpaired oviduct (fixation 5 min. after injection of sperm) $10 x$

appr.8: 1 - stingy apparatus;

2 - musk; 3 - sting chamber; 4 - artificial mating sign; 5 - sperm labeled with the fluorescent membrane probe $\mathrm{C} ; 6$ - sperm labeled with the

fluorescent membrane probe B;

7 - sperm labeled with

the fluorescent membrane probe A;

$$
8 \text { - vagina valve }
$$

section of the sting chamber in the zone of the vagina valve was mostly filled with the sperm marked with probe $\mathrm{C}$. Vagina valve, on the histological section, at its height was vectored to the side of the exit from the sting chamber. At this stage of sperm's migration from the sting chamber to the oviducts of the queen bee there was no intensive blending of reproductive product of different drones, on the histological section it was possible to clearly distinguish sections with sperm, marked with probes $A$ and B. Besides, within this period any active moving of sperm from sting chamber to oviducts was not observed.

30 mins after the fixing queen bees (pic. 2), stained portions of sperm partly moved to oviducts but were not found in the spermatheca. The sperm which was in the oviducts was blended. In the portions of sperm, stained by the fluorescent probe $\mathrm{C}$ there was reproductive product marked by probes $\mathrm{A}$ and $\mathrm{B}$. Walls of paired oviducts insignificantly expanded.

In the course of the research of histological sections of the reproductive system of queen bees, which were fixed 60 min after sperm injection, the outcomes discussed below were established (pic. 3). Nearly $80 \%$ of the sperm moved to oviducts. Paired oviducts significantly enlarged in diameter. In there, closer to

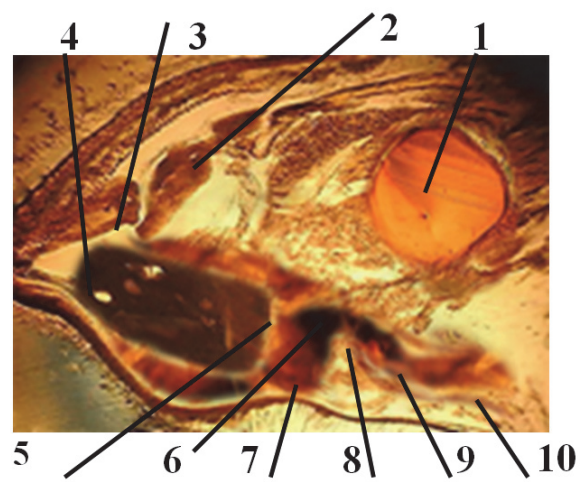

Pic. 2. Sagittal section of the reproductive system of the queen bee, undergone a single injection of sperm into the unpaired oviduct (fixation $\mathbf{3 0}$ min. after injection): 1 - spermatheca; 2 - stingy apparatus; 3 - sting chamber; 4 - artificial mating sign; 5 - sperm labeled with the fluorescent membrane probe A; 6 -sperm labeled with the fluorescent membrane probe $\mathrm{B} ; 7$ - sperm labeled with the fluorescent membrane probe $\mathrm{C} ; 8$ - vagina valve; 9 - unpaired oviduct; 10 - paired oviduct 
the ovaria, there was some sperm in less blended condition. Here it was possible to identify the parts where there was the sperm labeled with probes A, B, and C. And the biggest part of the drones' reproductive product, from the central part of the paired oviducts closer to ovaria, was filled with the sperm with probe $\mathrm{A}$, the one, which was injected into the queen bee the last. Beginning from the middle of the paired oviducts and further, up to the exit from the vagina, the portion was so blended up that it turned out to be impossible to find any solid sections marked with this or that probe of sperm. In the sting chamber, the labeled portions of sperm were less mixed up. Here it could be possible to distinguish separate sections, wherein the overall mass of the drones' reproductive product, there were clots of sperm marked with probes $\mathrm{A}, \mathrm{B}$, and C. By the moment of fixation, the mating sign still remained in these queen bees. First portions of the sperm labeled with the fluorescent probe got into the spermatheca. It is conceivable that the walls of the oviducts make some pressure on sperm, and due to muscular activity and movements of the belly, it starts running to the spermatheca. We didn't fix running out of sperm into the sting chamber, as a vaginal valve and possibly belly movements still provided its coming out from the oviducts.

Histological slices received from the queen bees, which were fixed 60 and 80 min after injection of sperm, showed (pic. 3-5) that sperm in the reproductive tracts and spermatheca is in mixed condition. The intensity of sperm migration to oviducts decreases, but to the spermatheca, on the contrary, increases.

On examination of the histological sections of the queen bees' reproductive system, which were fixed in 12 hours,

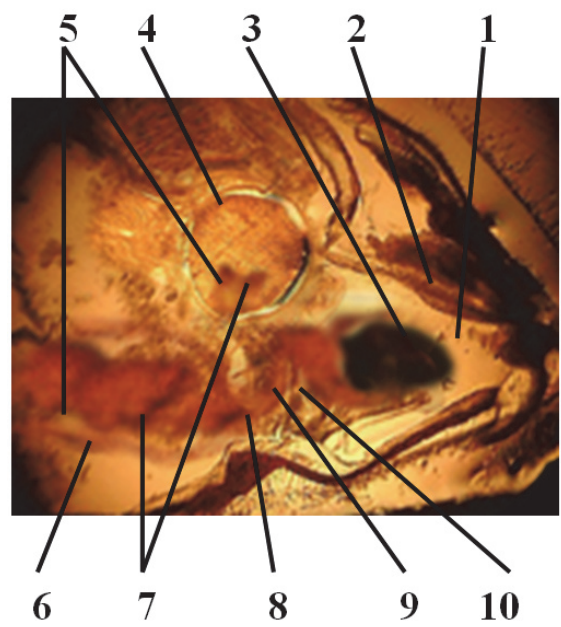

Pic. 3. Sagittal section of the reproductive system of the queen bee, which has undergone a single injection of sperm into the unpaired oviduct

(fixation $60 \mathrm{~min}$. after injection

of sperm) 10x appr.8: 1 - sting chamber; 2 -stingy apparatus; 3 - artificial mating sign; 4 - spermatheca; 5 - sperm marked with the fluorescent membrane probe A;

6 - paired oviduct; 7 -sperm marked with the fluorescent membrane probe B; 8 - unpaired oviduct; 9 - sperm marked with the fluorescent membrane probe $\mathrm{C}$;

10 - vaginal valve

one could see that there was no mating sign in the sting chamber any more (pic. 6). Remains of sperm which didn't get to the spermatheca were mostly in the sting chamber and an unpaired oviduct (vaginal valve zone). All the portions of sperm, which were in the reproductive tracts of the queen bee, intensively mixed up.

Therefore, while moving to the oviducts portions of sperm mix up in the sting camera. It may happen that this process also continues in the canal of the vagina. As for the oviducts, due to the results of the histological research of migration of sperm of different drones, 


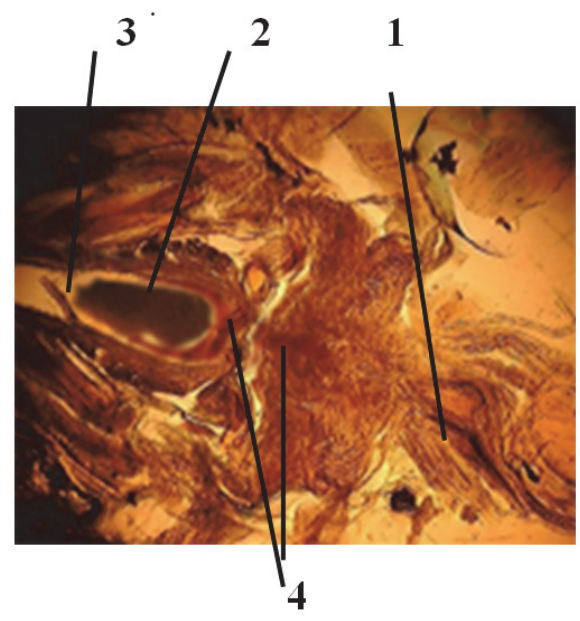

Pic. 4. Transversal section of the reproductive system of the queen bee, which has undergone a single injection of sperm into the unpaired oviduct (fixation $60 \mathrm{~min}$. after injection of sperm) 10x appr.8: 1 - sting chamber; 2 - artificial mating sign; 3 - sting chamber; 4 - sperm marked with the fluorescent membrane probe A; B; C

received by us while applying generally accepted technology of artificial injection of sperm, this process almost never takes place.

It was proved that after injection of sperm in the zone of the vagina opening, reproductive product of drones gets to the oviducts already in $30-60 \mathrm{~min}$. This process is evidently enabled by muscle activity of the belly's segments, vaginal valve, and active movements of spermatozoids. Sperm of different drones intensively mixes up in the sting chamber, in the oviducts this process almost never happens. It is likely that in the oviducts spermatozoids make their activity less intensive due to some factors (secretions, which can be exported from the walls of the oviducts, lack of air, temperature changes, etc.) It has a positive influence on the processes of sperm's migration.
Firstly, sperm won't intensively leak out. Secondly, efferent duct, having a short diameter, isn't able to maintain moving of large portions of sperm to the spermatheca. Although a vaginal valve slows down moving of sperm from the oviducts to the sting chamber, it still remains open. (pic.1-3, 5, 6). The canal over the vaginal valve, which is now formed, is significantly larger than the efferent duct of the spermatheca.

Examining of histological sections of the reproductive system of queen bees, which were fixed with different intervals, proved that migration of drones' sperm is actually over in a 24-hour period. Herein, the majority of sperm, which runs to spermatheca comes from those portions which were in the zone of unpaired and to the middle of paired oviducts. The sperm which was in more

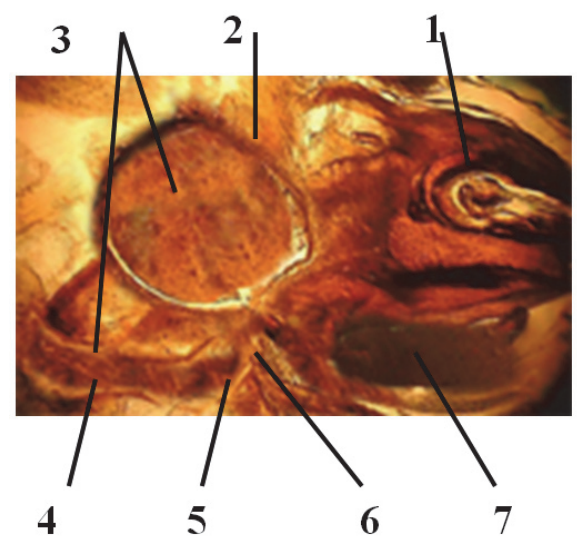

Pic. 5. Sagittal section of the reproductive system of the queen bee, which has undergone a single injection of sperm into the unpaired oviduct (fixation 80 min. after injection of sperm) 10x appr.8: 1 - Stingy apparatus; 2 - Spermatheca; 3 - sperm marked by the fluorescent membrane probes A, B, C; 4 - paired oviduct; 5 - unpaired oviduct; 6 - vaginal valve; 7 - artificial mating sign 
remote parts of paired oviducts practically didn't get to the spermatheca but ran outside.

Spreading of sperm in the spermatheca of queen bees, to be injected by sperm in the zone of vagina only once, differed from what we received in the case where the reproductive product of drones was injected in oviducts (Brovarskiy, 1987). Analysis of histological sections showed that irrespectively from the volume ratio of the portions, which were injected in the queen bees, the sperm in the spermatheca was in mixed condition. (pic. 5, 6). Examination of sections under a microscope showed that no regular redistributions of even separate slots of sperm of one and the same color of luminescence were found.

Sperm stained with probes A, B, C spread on the entire area of the spermatheca practically evenly. In spite of this, still, in some parts of histological sections correlation changed in favor of one of the stained portions of sperm. In group 3 where the queen bees received $3 \mathrm{mcl}$ of sperm marked with probe B more, on the entire area of sections of the sperm receiver dominated reproductive product, stained with this fluorescent probe (pic. 6).

That grounds for considering that while migrating from the sting chamber to oviducts and from there to spermatheca, sperm ejaculators mixed with each other. Thus, at occurring once the injection of sperm in the vagina zone and at the only flight of the queen bee for mating, the reproductive product of different drones after the migration is in the spermatheca in mixed condition. Such queen bees will breed young bees, which will have a different inheritance on father's succession but with domination of the drone whose sperm got to the spermatheca in a larger amount.

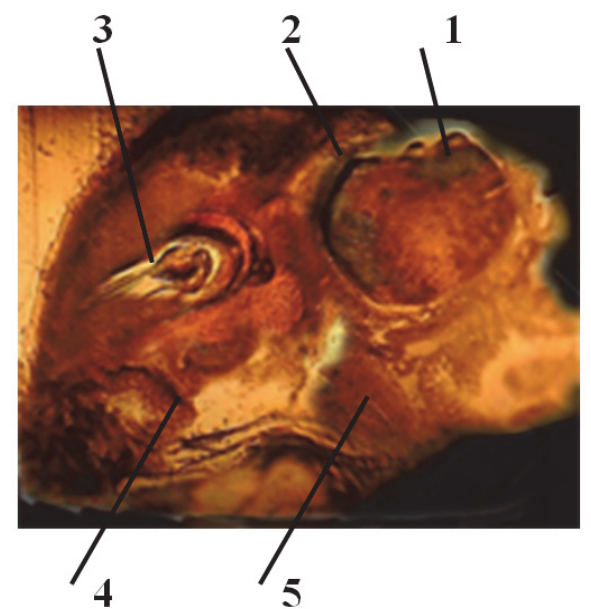

Pic. 6. Sagittal section of the reproductive system of the queen bee, which has undergone a single injection of sperm into the unpaired oviduct (fixation 12 hours. after injection of sperm) 10x appr.8: 1 - sperm labeled with the fluorescent membrane probes A, $\mathrm{B}, \mathrm{C}$ clots of sperm in the sting chamber; 2 - spermatheca; 3 - stingy apparatus; 4 - clots of sperm in the sting chamber;

$$
5 \text { - vaginal valve }
$$

Analysis of histological sections of the spermathecas of the queen bees, which received sperm in the vaginal zone, allowed to find out (pic. 7-11) that at the third injection, the placement of the layers of sperm marked with fluorescent probes, reminds of the distribution typical for those queen bees in which reproductive product was injected using generally accepted technology (Brovarskiy, 1987).

Portions of labeled sperm located in the spermatheca by way of C-shaped clots without a presence in their zone of any parts stained with the other probes. On the demonstrative histological sections, it can be clearly seen the following: reproductive tracts and positions of the layers of sperm marked with fluorescent probes A, 


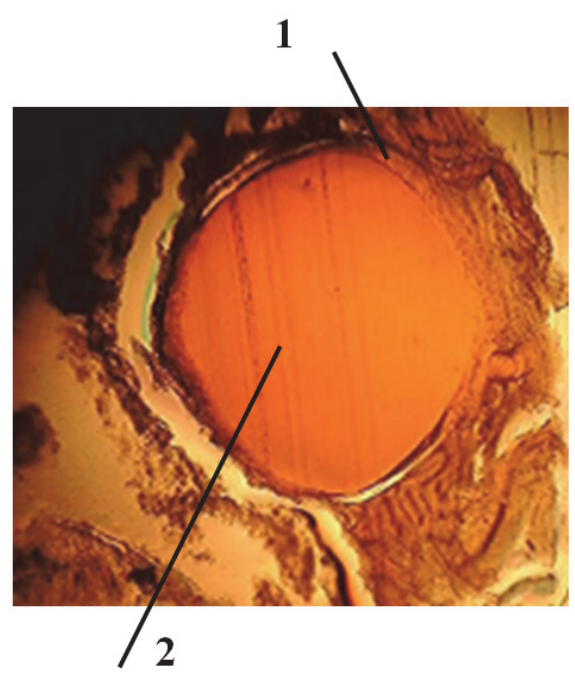

Pic. 7. Sagittal section of the reproductive system of the queen bee, which has undergone a single injection of sperm into the unpaired oviduct

(fixation $5 \mathrm{~min}$. after injection of sperm) 10x appr.8: 1 - spermatheca; 2 - internal part of the filled with liquid

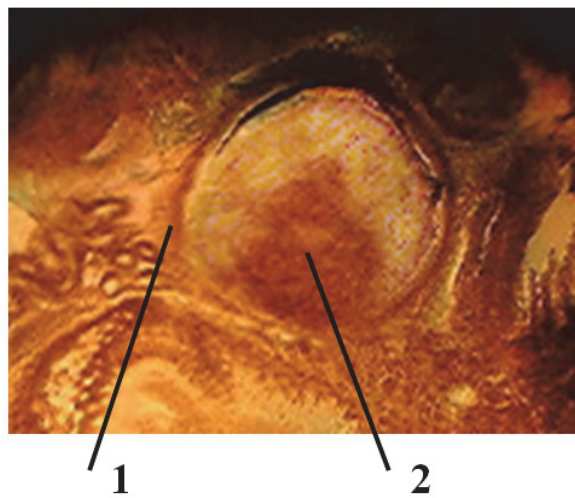

Pic. 8. Sagittal section of the reproductive system of the queen bee, which has undergone a single injection of sperm into the unpaired oviduct

(fixation $30 \mathrm{~min}$. after injection of sperm) 10x appr.8: 1 - spermatheca;

2 - sperm marked with fluorescent membrane probe $\mathrm{C}$

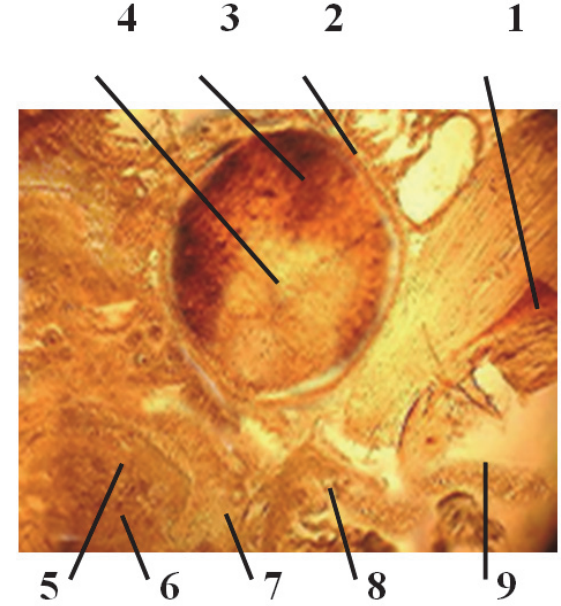

Pic. 9. Sagittal section of the reproductive system of the queen bee, which has undergone a single injection of sperm into the unpaired oviduct (fixation $80 \mathrm{~min}$. after injection of sperm) 10x appr.8: 1 - stingy apparatus;

2 -spermatheca; 3 - sperm labeled with the fluorescent membrane probe $\mathrm{C}$; 4 - sperm labeled with the fluorescent membrane probe $\mathrm{B} ; 5$-sperm labeled with the fluorescent membrane probe A; 6 - paired oviduct; 7 - unpaired oviduct;

8 - vaginal valve; 9 - clots of sperm in the sting camera

$\mathrm{B}, \mathrm{C}$ in the spermathecas of queen bees. Analyzing these section one can suppose that using the sperm from the spermathe$\mathrm{ca}$, in the process of reproductive activity of a queen bee spermatozoids got into excretory canal both from the central and side zones located close to the exit At the entry of sperm in the canal of the spermathecal reproductive cells of different drones mix up. This explains the presence of working species of different origin in bee colonies. However, the ratio of the breed by the father's background will depend on the amount and disposition of sperm of different drones in the zone of the excretory canal of the spermatheca. 


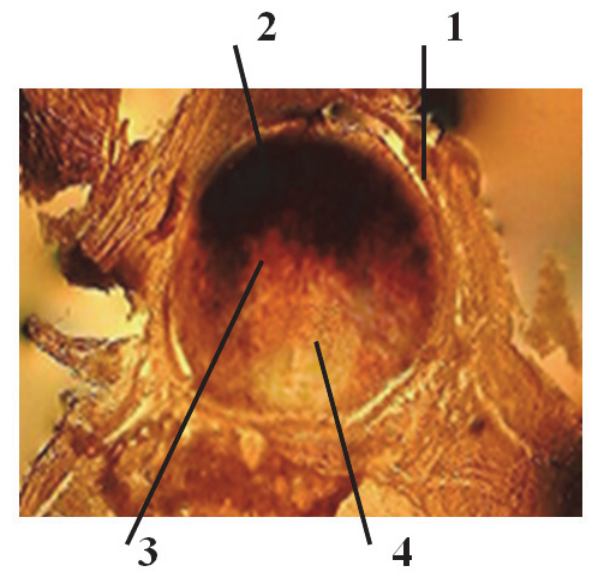

Pic. 10. Sagittal section

of the reproductive system of the queen bee, which has undergone a single injection of sperm into the unpaired oviduct (fixation 36 hours. after injection of sperm) 10x appr.8:

1 - spermatheca; 2 - sperm labeled with the fluorescent membrane probe $\mathrm{C}$; 3 - sperm labeled with the fluorescent membrane probe B; 4 - sperm labeled with the fluorescent membrane probe $\mathrm{A}$

\section{Discussion.}

Based on the above stated it could be said that the way, frequency and sequence of injection of ejaculators of drones' sperm into the reproductive tracts of the queen bee influence the distribution of the reproductive product in the spermatheca.

Taking into consideration the fact that in natural conditions during the queen bee's pairing with drones, the sperm gets into the zone of the opening of the vagina, then, in this case, several variants of its migration in reproductive tracts can be possible, as well as disposition in the spermatheca and further usage. It will depend on the frequency of the queen bee's pairing. For example, if the queen bee flies for pairing only once, the sperm of different drones will mix up

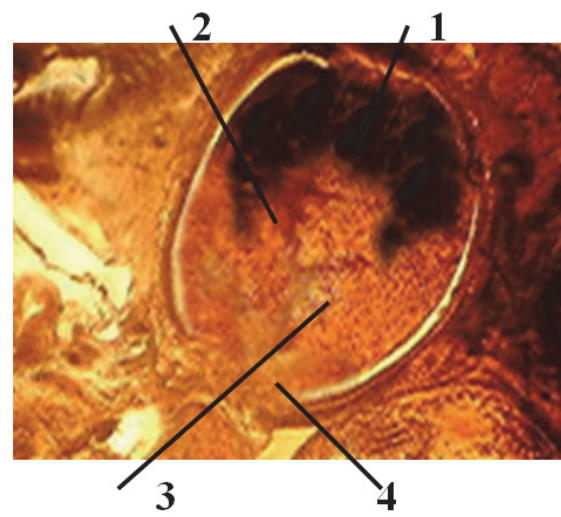

Pic. 11. Sagittal section of the reproductive system of the queen bee, which has undergone a single injection of sperm into the unpaired oviduct (fixation 36 hours. after injection of sperm) 10x appr.8: 1 - spermatheca; 2 - sperm marked with the fluorescent membrane probe $\mathrm{C} ; 3$ - sperm marked with the fluorescent membrane probe $\mathrm{B}$; 4 -sperm marked with the fluorescent membrane probe $\mathrm{A}$

during migration. On the contrary, in case of several flights, portions of drones' sperm which will get into the opening of the vagina, will be disposed in the spermatheca in C-shaped layers. For a bee colony, it turns better to have an only pairing of a queen bee with drones.

In the case of the intensive blending of sperm of different drones, the queen bee during the lifetime will produce young bees, differ by father's breeding background. In our opinion, presence in a colony of generations of working species, which differ by father's breeding background, allows honey bees to avoid such negative consequences as the emergence of lethal eggs, inbreeding depression. Besides, working bees in such colonies are more proof against the action of negative factors (diseases, 
weather conditions, etc.), which has a positive effect on their productivity and development. On the contrary, partial mixing up of sperm of different drones in the spermathecal, which occurs after repeated flights, may worsen the state of the colonies where such queen bees are working, as their breed, by reason of lack of variety, will be more perceptive to the influence of negative factors.

For the experts working at the breeding farms, those families are more attractive which give congeneric by father's breeding young bees. Using of technology of artificial injection of sperm allows controlling the reproduction of the offspring of known nature. This technology, depending on the way and frequency of injection of sperm, allows, at a point, to control the process of usage of drones' reproductive product. We have established the pattern of absence of intensive mixing up of drones' sperm during its moving to the spermatheca, and its injection into the unpaired oviduct of the queen bee gives a possibility to make corrections in this process. A sharp falloff in the intensity of blending of sperm in the oviducts may be connected with less intensive activeness of spermatozoids. To get more congeneric offspring by father's breeding from the queen bees, which were injected with the sperm of different drones into the zone of the opening of the vagina, only multiple intakes of ejaculators must be done.

It is due to the fact that solitary injection of sperm of one or several drones allows avoiding mixing up of separate portions of reproductive of males for the period of migration in the reproductive tracts of the queen bee. On the contrary, a single injection of sperm in the zone of the opening of the vagina will result in its blending during the period migration to the spermatheca, and that's why the offspring, which will be got from diploid eggs, will differ by father's breeding background.

\section{References}

1. Brovarskiy, V.D. (1987). O raspolozhenii spermy $v$ semyapriemnike pchelinoy matki [About distribution of sperm in spermatheca of the queen bee]. Selection and reproduction of the stratified breeds of bees. Col. Of sc. Works SRI of bee-farming. Rybnoe, 200205.

2. Brovarskyi, V. D., Pototskyi, M. K. (1999). Metodyka histolohichnykh doslidzhen statevoi systemy bdzholynykh matok [Methodology of histological research of the reproductive system of queen bees]. Scientific Bulletin of Lviv academy of veterinary after S. Z. Hzhytskyi, 3 (part I), 4-6.

3. Brovarskiy, V. D. (2000). Raspredelenie spermy trutney $v$ semyapriemnike pchelinoy matki [Distribution of sperm of drones in the spermatheca of the queen bee]. Col. Of scient. Works SRI of bee farming. Rybno: State institution Scientific research institute of bee farming, 126-127.

4. Browarskij, W. D. (2004). Nowy sposób sztucznego unasieniania matek pszczelich. Pszczelarstwo, 2, 25.

5. Ruttner, F. (1976). The Instrumental Insemination of the Queen Bee. Bucharest: Apimondia, 4-101.

6. Ruttner, H. (1976). Untersuchungen über die Flugaktivität und das Paarungsverhalten der Drohnen 6. Flug auf und über Höhenrücken. Apidologie, 7, 8, 331-341.

7. Ruttner, F. (1989). Hochzeitsflug der Königinnen und Drohnen. Bienenvater, 110, 5, 178-184.

8. Schley, P. (1988). An important improvement in the insemination technique of queen honey bees. American Bee Journal, 128, 4, 282-284.

9. Scrive, J. (1989). Insemination instrumentale (suite) Perfectionnernent. // Rev. franc. Apicultur, 484, 169-170. 
10. Winston, Mark L. (1991). The Biology of the Honey Bee. England, London: Harvard University Press Cambridge, Massachusetts, 281.
11. Woyke, J., Lasinski, Z. (1992). Natural mating of instrumentally inseminated queen bees. Apidologie, 23, 23, 225-230.

\section{В. Д. БРОВарСЬКИЙ (2019). ГІСТОЛОГІЧНІ ДОСЛІДЖЕННЯ МІГРАЦІЇ СПЕРМИ ТРУТНІВ У СТАТЕВИХ ШЛЯХАХ МАТОК. ANIMAL SCIENCE AND FOOD \\ TECHNOLOGY, 10(2): 12-21. https://doi.org/10.31548/animal2019.02.012}

Анотація. Проведено дослідження міграції сперми трутнів, маркованої флуоресцентними мембранними зондами, у статевій системі бджолиних маток за різних варіантів ії штучного введення. Бджолині матки були розподілені на три групи $(n=5)$. Maтки першої групи отримали сперму трутнів, марковану флуоресцентними мембранними зондами лише один раз, а другої та третьої - три рази. Кожна матка першої та другої групи отримала 9 мкл сперми (кількість кожної позначеної порції становила 3 мкл). Для маток третьої групи використовували іншу кількість сперми, (співвідношення: 2 мкл з зондом A, 5 мкл - зонд В і 2 мкл - з зондом C). Після того, як бджолині матки почали відкладати яйця, їх відловлювали та проводили дослідження репродуктивної системи. Отримані гістологічні зрізи досліджували під мікроскопом, описували і фотографували. Встановлено, що індивідуальні дози сперми різних трутнів за введення в яйцепроводи матки, мігруючи у спермоприймач розміщуються пошарово без суттєвого змішування. 3'ясовано, що в непарному та парних яйцепроводах сперматозоїди втрачають рухливість. Навпаки, за введення сперми у зону отвору піхви бджолиної матки сперматозоїди продовжують активно рухатись. Доведено, що у процесі фізіологічної функції витоку сперми для обсіменіння яєць відбувається купажування сперматозоїдів із різних порцій у зоні, що прилягає до сім'япроводу. Введення сперми у зону отвору піхви одноразовими порціями кількох трутнів сприяє змішуванню ії в процесі міграції в яйцепроводах і спермоприймачеві. Навпаки, за уособленого введення маркованих флуоресцентними мембранними зондами доз сперми трутнів через певні проміжки часу є можливість спрямовувати відтворну діяльність матки на одержання переважно однорідного потомства за батьківським походженням. За цього варіанту введення сперма різних трутнів розміщується у спермоприймачі матки пошарово, без суттєвого змішування.

Ключові слова: сперма трутнів, міграція, бджолина матка 